UDC 372.851

DOI: $10.23951 / 2782-2575-2021-2-88-100$

\title{
THE CONCEPT OF TEACHING MATHEMATICS IN THE 1ST GRADE OF A GENERAL EDUCATION SCHOOL
}

\author{
A.A. Nikitin ${ }^{1,2}$, O.A. Nikitina ${ }^{2}$ \\ ${ }^{1}$ Sobolev Institute of Mathematics, Novosibirsk, Russian Federation \\ ${ }^{2}$ Novosibirsk State University, Novosibirsk, Russian Federation
}

The teaching of mathematics should reflect the global trends in the development of mathematical and pedagogical scientific thought. The authors develop guidelines for studying mathematics in the 1st grade based on the Federal State Educational Standard. Thus, the structure and the form of the textbook content are described by chapter. The theoretical part should allow students to complete screening questions, univariate and multivariate tests, problems, and exercises. Each chapter of the developed textbook is divided into paragraphs, and each paragraph is divided into items. One item of theoretical material contains either a new idea to study or a set of interrelated concepts that define a new idea. According to this, it is possible to form mathematical knowledge trajectories. So, there are broad opportunities to transform knowledge elements into multimedia forms, including presentations, videos, test modules, and other newly emerging means of representation and visualization, using the achievements of artificial intelligence. It is possible to define main themes such as natural numbers counting, acquaintance with geometric shapes, comparison of objects in the value and quantity, acquaintance with a squared paper and measurement standards, the study of objects position, the sets consideration, introduction to the algorithm concept can. The authors' conceptual directions of teaching mathematics in the 1st grade provide the foundation for mathematical education in general education schools for all the years of study.

Keywords: primary education, general education, teaching, mathematics, knowledge element.

Mathematics is one of the fundamental disciplines of education. Traditionally, mathematics is given almost the same number of hours as learning the native language. Moreover, we can say that mathematics is an element of mass culture.

Starting from the 1st grade of primary school, the teaching of mathematics should reflect the global trends in mathematical and pedagogical scientific thought development and represent the projection of mathematical science on school education without distortions and simplifications.

The appearance, development, and maintenance of interest in mathematics begin with forming clear and consistent ideas about the subject. Therefore, the content of the training should be constructed in such a way that the logic of perception of the newly introduced concepts is consistent, there should be repeated references to the studied topic, and a way to control the assimilation of the knowledge. There should be a set of tasks of various types that transforms the studied material into knowledge.

In this regard, students should have the opportunity to learn from a textbook that explains the topic, and provides examples and tasks that allow them to make conclusions to consolidate the studied material. The textbook is a necessary tool to teach new elements of knowledge and make

* Original Russian language version of the article: Nikitin A.A., Nikitina O.A. Napravleniya obucheniya matematike $\vee$ 1-m klasse obshcheobrazovatel'noy shkoly [Conceptual Guidelines of Teaching Mathematics in the 1st Grade of a General Education School]. Nauchnopedagogicheskoye obozreniye - Pedagogical Review, 2021, vol. 3 (37), pp. 172-185. DOI: 10.23951/2307-6127-2021-3-172-185 
them familiar to the students. While reading a fiction book, we carefully follow the characters and the development of the plot. Similarly, reading a textbook, the student should see how concepts are introduced, and more complex relationships are revealed, forming a complete picture. The textbook should be designed so that students can study it with the help of a teacher or adults and independently understand and master the material.

A.A. Nikitin, A.P. Efremov, and I. V. Silantiev in 2006 introduced the concept of episteme from the pedagogy point of view as a specific conventional measurement unit [1, p. 4]. In further studies, the episteme was considered an element of knowledge in application to the learning processes and knowledge formation in general [2, p. 6]. Based on this, it became possible to form and compare the elements of knowledge from a unified point of view. To determine the qualitative and quantitative characteristics of the status, development, and perspective vision of various parts of the education content and the organization of the learning process, including the standards, curricula, plans, textbooks, and other elements of pedagogical and methodological support for learning, taking into account the equability and equivalence of the knowledge elements, taking into account the time of their presentation and assimilation [3].

Approaching the textbook writing from the point of view of dividing it into elements of knowledge, when each topic item in the textbook contains one new idea to study, a natural opportunity opens up to form the trajectories of mathematical learning. This is also related to the idea of creating hierarchical multivariate tests, when chains are formed, the links of which are the test conditions, the answers, and the corresponding conclusions [4]. Any hierarchical test is equivalent to a suitable single-level multivariate test, where the variants of the proposed solutions are true/false hierarchical tests. Such mathematical knowledge trajectories and hierarchical tests that have a given range, that is, the depth and breadth of the study of a particular topic, open up the possibility of converting them into various types of multimedia forms, including presentations, videos, test modules, and other newly emerging means of representation and visualization, as well as the use of artificial intelligence achievements.

Primary school maths education is humanitarian since mathematics teaches to think, formulate thoughts accurately, develop the ability to follow the rules, reason, draw conclusions, and make independent decisions.

To build a unified vertical of mathematical education in a secondary school, the authors set a goal to format the teaching in the 1st grade and in primary school in such a way that it is consistent with the concept of teaching proposed by the authors of multi-level textbooks in mathematics for grades 5-11 of general education schools [5-22].

When teaching mathematics in the 1st grade, six main directions can be identified that ensure the Federal State Educational Standard (FSES) implementation.

The first direction reflects the counting of natural numbers in ascending and descending order, the direct and reverse counting of numbers, the use of direct and reverse counting in determining the actions of addition and subtraction, and includes the interpretation of this using a ruler. In this regard, the elements used in addition and subtraction are considered: sum, summands, difference, minuend, subtrahend and their relationships, the properties of 'numbers' equalities, the commutative property of addition are studied, the tables of addition and subtraction of numbers are considered. For natural numbers from 1 to 20 and the number 0 , quantitative and ordinal numbers are determined, the enumeration, ordering, and comparison of these numbers are studied, as well as finding the unknown component of addition, modeling, and solving text problems in one action for comparison, addition, and subtraction, counting with twos, fives, acquaintance with the concepts of even and odd numbers, and partition an even number in half is considered. An essential element of learning in the 1st grade is memorizing the addition and 
subtraction tables from 0 to 20 . The elements of this direction allow to form associations and serve as a basis for further study of natural numbers.

The second direction is related to the study of the 'object's position, including the establishment of left and right relations, in front and behind, above and below, between, as well as left and right from the point of view of another person, with movement to the left/right, up/ down, in opposite directions. In addition, examples of relationships between an object and its reflection are considered. Copying images made up of points and segments on checkered paper is also considered. This direction will be developed by introducing coordinates on the plane and in space in the future.

The third direction refers to the acquaintance with geometric shapes: point, segment, straight line, plane, the angle between segments, triangle, right angle, rectangle, square, quadrilateral, polygon, circumference, circle, cube, and sphere. Some characteristics of these shapes are given. This direction serves as the basis for operating with geometric objects.

The fourth direction relates to the comparison of objects in size and quantity, acquaintance with checkered paper, the study of the concept of a measurement standard, and the consideration of measure standards examples, the use of units of length measurement, including centimeter, decimeter, and the ratio between them, and the acquaintance with ancient measures of length. The same segment may have different lengths when using different measurement standards. Thus, the relations between the concept of a segment and the properties of the segment length are determined. In addition, the comparison of objects by length is considered with the establishment of relations between them: "long/short" "high/low" "wide/narrow," and the difference comparison of the lengths "more/less" is performed. This direction will determine the area and volume of shapes, obtaining other quantitative characteristics of geometric shapes.

The fifth direction refers to the consideration of sets of elements, intersections of sets, inclusions in a set, the ability to classify and group elements by attributes, as well as to the consideration of types of elementary logical statements, including true (correct), false (incorrect), and indefinite. This direction is fundamental in modern mathematics.

The sixth direction is associated with introducing the concept of an algorithm, implementation of simple algorithms for calculations, length measurements, and geometric shapes construction. This direction serves as the primary basis for determining the algorithm and is further developed in mathematics and computer science courses.

These directions are closely related to each other, and are sometimes intertwined with one another, each helping the other develop.

Concerning these directions, the mathematics textbook for the 1st grade should have a particular structure. The general logic of the initial study of mathematics should be built, considering the mathematics studying logic in grades 5-11 to form a unified vertical of mathematical education in grades $1-11$.

In this regard, it is advisable to rearrange the theoretical material with great care since the subsequent presentation, as a rule, is based on the previous material, and the logic of the presentation may be lost during the rearrangements. Omissions of the material being studied can also lead to logical gaps in perception.

The developed textbook $[23,24]$ consists of chapters, which consist of paragraphs divided into topic items. The textbook contains a subject index, answers, instructions for problems and exercises, and a detailed table of contents.

Each chapter contains from one to six paragraphs.

Each paragraph includes no more than 6 points of material to study. One topic item of theoretical material contains either one new idea to study or a set of interrelated concepts that 
define a new idea. Some items refer to the increased level of difficulty and complexity for a given year of study. Nevertheless, they are essential and valuable for compliance with the Federal State Education Standards requirements.

Each topic item of theoretical material ends with an open question. Such topic questions are an integral part of the theoretical material, and they either develop topic item material or point to the examples of practical applications of the material considered in the topic item. The answers to the open questions may not be directly embedded in the text. As a result, students can expect a variety of correct answers to these open questions.

Each paragraph ends with a set of control questions for the theoretical material. The control questions capture the main ideas of the paragraph. The answers to these questions are embedded in the text of the studied paragraph.

Students must answer all open questions for each topic item and all control questions since these questions relate to the concepts and properties being studied.

The implementation of some ideas is transferred to tests, problems, and exercises to reduce the theoretical text's size. Therefore the tests, problems, and exercises are considered an integral part of the material being studied.

For each paragraph, there are two single-variant tests offered, which have only one correct answer. In addition, there are two multivariate tests offered for each paragraph, which have two, three, or four correct answers. When considering multivariate tests, it is mandatory to examine all correct and incorrect answers and justify them. A multivariate test is considered solved when all the correct answers are indicated correctly and all the incorrect answers are determined and explained.

Each paragraph contains eight problems and exercises. Problems and exercises represent the applications of the paragraph's theoretical part. The textbook provides keys to problems and exercises, and in some cases, provides instructions for solving the problems.

We want to mention that all tests, problems, and exercises are directly related to the theoretical material of the paragraph and are aimed at mastering, controlling, and memorizing the concepts and properties studied in the paragraph. Tests, problems, and exercises allow students to see the diversity of concepts and properties in everyday life. At the same time, the material's presentation is constructed so that the concepts considered earlier are accepted as known, and the further presentation is based on these concepts. As a result, the studied material is repeated, an appeal to previously studied concepts, and their new relationships are discovered.

Answers to tests, problems, and exercises can directly follow the theoretical material or expand the angle of view on the studied concepts. This teaches students to reflect on the questions posed.

We assume that students should know the solutions to all tests, all problems, and exercises for the paragraphs, since some ideas found in tests, problems and exercises are further developed both in theory and in other tests, problems, and exercises.

Let us mention that there are tests, problems, and exercises of an increased difficulty level and complexity that require additional thinking, or the answer is not immediately obvious and requires several steps of reasoning. Such tests, problems, and exercises are marked with an "*."

The presentation of the material in the textbook is supported by a variety of examples that form associations with practical, real-life situations. For example, paintings by famous artists, literary examples, including fairy tales, proverbs, riddles, epics, as well as various gaming and everyday circumstances are used. This allows us to form interdisciplinary connections between mathematics and language, physics, history, geography, biology, physical culture, art, and music. 
There are two types of images in the textbook: one type is for imaginative perception and animation of the text, the other one is directly based on theoretical material, tests, problems, and exercises.

Tables and pictures in the texts are intentionally marked with letters of the Russian alphabet. This allows students to memorize the sequence of the letters in the alphabet.

The newly introduced mathematical concepts are highlighted in an italic font and are given in the textbook subject index with the page number. Some definitions and rules are enclosed into frames and require memorization and learning by heart.

The authors believe that pre-reading of upcoming topics or reading them with adults is one of the critical elements of learning in general. Pre-reading during homework can increase the class's learning efficiency, help students overcome the fear of new material, and strengthen their confidence in studying mathematics.

The mathematics textbook for the 1st grade is accompanied by a teacher's book, which reveals the textbook ideas and content to ensure the same perception of the educational material as the textbook's authors imply. In this regard, we consider implementing the following:

- ensuring teachers understand the intention of the author

- provide teachers with the opportunity to give the studied material as close as possible to the material given in the textbook

- allow students to master the educational material with the help of the textbook and teachers.

The above implementation allows students to gain a high level of mathematical knowledge, corresponding to the generally accepted world practice.

Primary school students typically have a surface or intuitive knowledge of people, animals, objects, and the world around them, so we shall focus on imaginative perception. In this regard, some examples of geometric shapes and concepts are considered, numerical models are given, and mathematical concepts such as direction, sequence, and comparison are considered.

For a general statement to become clear, sometimes illustrative examples are required to create the necessary associations. Getting used to new concepts is carried out gradually on the most straightforward models with repeated actions. The introduction of new ideas is based on analogies with the knowledge previously studied or available to students.

Natural numbers are those numbers used for counting. In particular, acquaintance with the natural numbers from 1 to 9 allows one to determine the quantitative and ordinal numbers, establish the enumeration, order and compare these numbers, and explain the introduction to addition and subtraction arithmetic operations. The emphasis is on the counting and order of the natural numbers from 1 to 9. The question "How many?" helps to answer the quantitative numbers. Natural numbers from 1 to 9 are identified with their spoken word using digits. The number "one" is identified with the digit 1 , the number "two" is identified with the digit 2 , and so on. The ordinal numbers answer the question "Which one?/What is the order?." Therefore, the entry " 1 " carries several meanings - it is a digit denoting the number 1 , it is the quantitative number "one," and it is the ordinal number "first."

Counting from 1 to 9 is performed in ascending order. The examples in the textbook consider numbers that are neighboring and that are not neighboring for numbers from 1 to 9 . A sequential counting of numbers, where every two of them are neighboring and arranged in ascending order, is called direct counting. Examples of nondirect ascending counting are also given. During direct counting, a comparison of the "lesser" type is determined for natural numbers from 1 to 9 . The natural number that occurs in direct counting earlier will be less than the natural number that occurs later. The quantitative zero, which we denote with the digit 0 , and the zero ordinal number are introduced. It is stated that the number 0 is less than any natural number. 
In the world around us, the objects are arranged differently. To determine the object's locations relative to each other, we normally use the following: left, right, under, on, over, between. In this regard, you can also set the "right" and "left" positions for another person's perspective. The simplest geometric shapes are a point, a segment, and plane figures. Different directions of movement are considered: left, right, up, down. As a result, when moving along a segment from its beginning to its end, it is necessary to know the point from which the movement started, in which direction it moves, and, finally, the segment that should be passed. A connection is established between the object and its reflection. In this regard, examples of symmetrical shapes are given, and it is determined that a shape on a piece of paper is symmetrical if it is possible to draw such a segment that, by bending the sheet along this segment, the two parts would align with each other.

Next, we should explain how the ruler is designed: why the larger markings are placed on the ruler, what is the beginning of measurements on the ruler, which large markings are neighboring, how the gaps between large markings are determined. If one moves along the ruler to the right from the zero marking using larger markings, the numbers increase, and we use direct counting. A descending counting and a reverse counting of numbers from 9 to 0 are determined too. A sequential counting of numbers, where every two numbers are neighboring and arranged in descending order, is called reverse counting. Using the "less" type comparison, the "more" type is determined. It is mentioned that any natural number is greater than zero. It is determined that among two numbers, the number on the ruler to the right from the zero mark is greater than the other one. Examples of determining the largest number and the smallest number from a set of numbers are given.

Students are introduced to the addition operation, writing numeric expressions using the plus "+" and the equal "=" signs. The components and results of the addition are defined and distinguished - the summands and the sum. It is mentioned that the phrase "sum of summands" can be understood in two ways: the sum of summands means either the sum value or the entry of summands connected by the "+" sign. The commutative property of numbers, in addition, is formulated, the knowledge and understanding of the meaning of which should become an organic part of the mathematical culture of a person. When studying addition operations, it is necessary to consider the properties of the numeric expressions' equalities. Students should learn these properties by heart. The properties of the number 0 , in addition, are considered.

The table structure is defined: what are the rows, the columns, and the cells of the table. We explain how the data is entered and extracted from tables. A general addition table is formed for numbers in the range from 0 to 3 . A detailed review of the addition tables on numbers in the range from 0 to 3 , considering the commutative property of addition, allows to extend this property to numbers from 4 to 9 and further.

Representation of numbers from 4 to 9 as the sum of two natural numbers is considered. The communicative property of addition is formulated for numbers from 4 to 9 while considering the properties of zero when adding. As a result, the sum of two natural numbers, and the sum of zero and a natural number are considered. Based on this, tables of numbers addition from 0 to 9 are formed, and the table data entry and extraction are considered. It is emphasized that the addition tables from 0 to 9 must be learned by heart.

Next, the arithmetic subtraction is introduced, using the minus sign "-_" and the equal sign "=." The components and results of subtraction actions are defined and distinguished as the minuend, the subtrahend, the difference. The difference means either the difference value or the record of the minuend and subtrahend, connected by the "-" sign. It is determined that the minuend is equal to the sum of the difference and the subtrahend. The properties of the number 0 
in subtraction are considered. A general subtraction table is formed for numbers from 0 to 3 when the difference between the numbers is a natural number or zero.

After the subtraction operations from 0 to 3 are introduced, and the corresponding subtraction tables are arranged, the subtraction from 0 to 9 and the numbers from 4 to 9 are considered by analogy, and the subtraction table for the numbers from 0 to 9 , when the difference is equal to a natural number or zero is given. In this case, the introduction and extraction of the data from the table are considered. Here the natural numbers difference comparison from 0 to 9 , where the minuend is greater than the subtrahend, is considered.

Students should understand that adding two numbers is related to direct number counting, and subtracting two numbers is associated with reverse number counting. To find the sum of two natural numbers using direct counting, one should add to the first natural number the number 1 in an amount equal to the second natural number. To subtract from the first natural number the second natural number using reverse counting, one should subtract from the first natural number the number 1 in an amount equal to the second natural number. The use of two rulers in addition and subtraction for numbers ranging from 0 to 9 is analyzed. The use of rulers allows us to see how the actions of addition and subtraction are performed, and the relationship between addition and subtraction is seen too.

Next, the unknown summand in addition and its designation in the sum is considered. When writing equality, the left and right sides of the expression are equalized. It is determined that the unknown summand is equal to the difference between the sum of two numbers and the known summand.

Then the natural numbers from ten to twenty are determined, and the order of their sequence is established. Each number is designated and written using two digits 10, 11, 12, 13, 14, 15, 16, $17,18,19,20$. There are representations of numbers from 10 to 20 as the sum of two or more summands, considering the commutative property of addition. The representation of numbers from 10 to 20 as the sum of two summands is also arranged in tables. The setup of the abacus and the representation of numbers from 0 to 20 is considered.

Let's consider the ordinal natural numbers from the tenth to the twentieth. Neighboring numbers are defined for numbers from 10 to 20. The direct counting of numbers from 10 to 20 and the reverse counting of numbers from 20 to 10 are introduced. Numbers from 0 to 9 are called one-digit numbers because they are written using one character - one digit. Numbers from 10 to 20 are called two-digit numbers since they are written using two characters - two digits. A comparison rule of the "less" type is defined for two natural numbers. This is used to determine the comparison of the "more" type. A rule for comparing three numbers and a rule for comparing one-digit numbers with two-digit numbers is formulated. A table of comparison for the "less" type numbers from 10 to 20 is introduced.

The subtraction from 10 to 20 of one-digit is considered. It is mentioned that for the difference between the numbers from 10 to 19 and the number 10, the difference value is equal to the second number on the left in the record of the minuend. The difference between the numbers 20 and 10 is 10. The difference between the number 20 and a two-digit number from 11 to 19 is defined as the difference between the number 10 and the second number on the left in the record of the subtrahend. The table of subtraction from numbers from 10 to 20 the one-digit numbers and the table of subtraction of two-digit numbers from 10 to 20 , when the difference between two numbers is a natural number or zero is considered.

Performing arithmetic operations of addition and subtraction for numbers ranging from 0 to 20 , memorizing addition and subtraction tables for these numbers lay the foundation for oral and 
written counting, which is in demand for every educated person throughout his life. This is an element of their culture and upbringing in general.

The concept of even and odd numbers is introduced. It is specified that the digits $0,2,4,6,8$ are even, and the digits 1, 3, 5, 7, 9 are odd. An even natural number ends in an even digit. An odd natural number ends in an odd digit. An even natural number follows every odd natural number, and every even natural number is followed by an odd natural number. The rules for determining the evenness and oddness of the sum of two summands depending on the evenness and oddness of these summands are formulated. Every even natural number is represented as the sum of two identical natural numbers and can be divided into two. Any odd natural number can be represented as the sum of the number 1 and an even number, and an odd number cannot be divided into two. There is the direct counting of numbers. Sometimes it is convenient to count in twos. For natural numbers within 20 , there is a sequential enumeration of numbers $2,4,6,8,10,12,14,16,18,20$, which is counting by twos. And there is also the enumeration 5, 10,15, 20, which is counting by fives.

Next, we consider a text as a mathematical problem. A text problem is like a short story from life, which performs some mathematical actions. Examples of text problems in one action for comparison, addition, and subtraction are considered. A text problem consists of a condition, and a question or requirement of what must be defined or resolved. The condition of a text problem is what is known. To solve a text problem, one should establish dependencies between known data and conduct reasoning that allows getting an answer to the question of the problem. When solving a text problem, modeling conditions and solutions can be used. A model of the problem is created: a description of the known data and actions that must be performed to solve and answer the problem. To solve text problems, one should learn how to read first. This allows us to recognize the relationships and make sense of the content. In this regard, the accuracy of the wording of the condition and question of the text problem is extremely important.

Each set is defined by the elements that are included in it. An attribute is a distinctive feature of an element that determines its entry into the set. The attributes can be, for example, shape, size, color. The elements can be classified by an attribute or can be grouped by individual attributes. Let's consider examples of patterns in sets. Examples of combining into one set, an intersection of sets, and inclusion into a set are given.

Some statements accurately describe the events of reality. Such statements are called correct or true statements. Some statements describe events or facts that do not happen. Such statements are called incorrect or false statements. Sometimes it is not possible to define whether the statement is true or false. This may require additional information. Such statements are called indefinite statements. Thus, logical statements are considered, and an elementary logical statement is determined. For each type of statement, examples from literature or life are given.

Magnitudes and measurements of magnitudes are considered. A quantity is something that can be measured. After measuring the magnitudes, they can be compared. Examples of comparison by magnitudes and by quantity are given. One of the examples of magnitudes and their measurements is the concept of length and the measurement of length. The measurement of many magnitudes is reduced to the measurement of segment lengths, so it is appropriate to start studying the measurement of the magnitude with the measurement of length. Using the example of a ruler, one can determine the length of the segment equal to one centimeter. This allows determining the length of the segment between two neighboring larger markings on the ruler. With the use of natural physical characteristics of body parts, it was possible in the past to determine the length of segments. In this connection, some old Russian measures of length are given: vershok, pyad (palm, five), lokot (elbow), arshin (yard), sazhen (fathom), verst (turn (of a 
plough)). It is not coincidental that a checkered paper is used in math lessons. It is a visual and convenient tool for recording and displaying various mathematical representations and concepts. When considering checkered paper made up of identical cells, the checkered paper grid, checkered paper nodes, including neighboring nodes, are determined. The standard of length and the standard of the checkered paper is considered the length of one cell's side. To determine the length of a given segment using length standards, one should count the number of standard segments contained in the measured segment. Examples of measurement standards are given: the length of the segment connecting the neighboring nodes of the checkered paper; the length of the segment equal to 1 centimeter; the length of the segment equal to 1 decimeter. One centimeter is equivalent to two standards of checkered paper, and one decimeter is equal to 10 centimeters. If the values are given in the same units of measurement, they can be added and subtracted using the rules for adding and subtracting numbers.

The equality of segments has certain properties: a segment is equal to itself; if the first segment is equal to the second segment, then the second segment is equal to the first one; if the first segment is equal to the second segment, and the second segment is equal to the third segment, then the first and third segments are equal. Segments are equal if and only if their lengths, measured in the same units of measurement, coincide. Thus, the segments can be compared by size using an overlay or using length measures. These two comparisons are consistent: if the segments are equal, then the lengths of these segments are equal; if one segment is smaller than the other, then this segment will be shorter than the other, and if one segment is larger than the other, then this segment will be longer than the other. The property of comparing three segments is considered: if the first segment is less than the second, and the second segment is less than the third, then the first segment is less than the third segment. Using the concept of the segment length, one can establish the relations between objects on the following examples: higher - lower, further-closer, wider-narrower. The concepts of height and width are defined. Suppose we consider two magnitudes that can be compared, and one of them is larger than the other, and the smaller magnitude can be subtracted from the larger magnitude. In that case, we can compare these magnitudes and thus determine how much one magnitude is smaller or how much it is larger than the other.

When drawing a segment, it is assumed that the segment is drawn using a ruler. The length of a segment is always equal to the sum of the length of the segment from its beginning to the inner point and the length of the segment from this inner point to the end of the segment. It is defined as how to get the points of the straight line where the given segment is located. If two segments have a common end, then they form an angle between the two segments. The common end of these segments is called the angle vertex. The segments themselves are called the sides of the angle. Next, we explain how to bend a sheet of paper in order to build a right angle. Examples of polygons are considered, including a triangle, a quadrilateral, a pentagon, and a hexagon. The concepts of vertices and sides of a polygon are introduced. Polygon designations are defined using vertex designations. For the sides of a triangle, the triangle inequality is always true: the length of one side of a triangle is always less than the sum of the lengths of the other two sides. Definitions of geometric shapes are given: rectangle, square, cube, and cube sweep. An example of how to draw a square on checkered paper is given. Vertices, edges, and faces are defined for the cube, and the cube sweeps are drawn. The points equidistant from the given point are determined. Using this definition, one can find the circumference, the circle, and the sphere, and the ball. For each of these shapes, the concepts of center and radius are defined. The boundary of a circle is circumference. The boundary of the ball is a sphere. 
It is necessary to understand the representation of points and segments to determine the shapes copying consisting of points and segments on checkered paper. When it is considered the representation of a point on a checkered paper, it is assumed that the point is located at the nodes of the cell. Segments connecting pairs of points are considered. Segments can have different locations: horizontal segments, vertical segments, and segments that are neither horizontal nor vertical. On the checkered paper, the movement to the right and left along the horizontal segment and up and down along the vertical segment are determined. Movement along a segment from one end to the other corresponds to movement along a horizontal segment on a certain number of cells sides and movement along a vertical segment on a certain number of cells sides. Copying a horizontal segment involves copying the point that is the beginning of the segment. Then, from the copy of the beginning of the segment, there is a movement along the horizontal grid line in the same direction as the end of the original segment, by the number of the cells' sides equal to the length of the original segment. Thus, there is a copy of the end of the segment. Connecting a copy of the beginning and a copy of the end of the segment, we get a horizontal segment that is a copy of the original horizontal segment. Copying a vertical segment involves copying the point that is the beginning of the segment. Then, from the copy of the beginning of the segment, there is a movement that takes place along the vertical grid line in the same direction as the end of the original segment, by the number of the cells' sides equal to the length of the original segment. Thus, we get a copy of the end segment. Connecting a copy of the beginning and a copy of the end of the segment, we get a vertical segment that is a copy of the original vertical segment. When copying a segment that is neither horizontal nor vertical, the copy of the point that is the beginning of the segment is made. Then we consider the location of the end of the original segment in relation to its beginning: how many sides the end of the segment has to the left or to the right, above or below the beginning of the segment. Having found this out, we find the end of the copied segment. Connecting a copy of the beginning and a copy of the end of the segment, we get a segment that is a copy of the original segment. Thus, to make a copy of a shape made up of points and segments on a checkered paper, it is necessary to mark copies of all points and copies of the ends of all segments, considering their location relative to each other, and then connect the ends of the copied segments.

To give the primary school student an initial understanding of an algorithm, examples of the simplest algorithms found in everyday life and those learned in math lessons shall be provided. We formulated that the algorithm consists of sets and rules for executing the algorithm. The sets for the algorithm include the following: an initial data set, a set of possible results, and a set of intermediate data. The algorithm execution rules include the algorithm start rule, the algorithmic process rule, and the algorithm termination rule. The data set for the algorithm is what is given. The set of possible results is the set of results obtained when all the steps of the algorithm are performed. A set of intermediate results is a set of those obtained when performing individual steps of the algorithm. The algorithm start rule is the definition of the first step of the algorithm. An algorithmic process rule is for determining each successive step of an algorithm using all the previous steps. The algorithm termination rule is the rule when all the algorithm steps are completed and a set of possible results is obtained. The use of the direct counting algorithm for calculating the sum of two natural numbers and the reverse counting algorithm for calculating the difference of two natural numbers is considered. The measurement of the segment length as an algorithm and the algorithms for constructing geometric shapes (a segment, a triangle, a circle) are considered.

Thus, the textbook on mathematics that is being developed for the 1st grade corresponds to the fundamental conceptual directions of the current stage of education development. It also 
contains theoretical and practical material, and allows the transmitting, perceiving, and controlling knowledge, which ensures the formation of a harmoniously developing personality with fundamental mathematical knowledge.

\section{References}

1. Nikitin A.A., Efremov A.P., Silantiev I.V. Analiz sistemy zachetnyh edinits: ot vysshey shkoly $k$ profil'nomu obucheniyu i specializirovannoy podgotovke $v$ obshcheobrazovatel'noy shkole [Analysis of credit system: from higher education to profile and specialized training in secondary school]. Edited by A.A. Nikitin. Novosibirsk: Editorial and publishing center of Novosibirsk State University, 2006. 200 p. (In Russian).

2. Nikitina O.A. Fundamental'nye epistemodidakticheskie issledovaniya pedagogicheskogo soderzhaniya $i$ organizacii obrazovatel'noy sredy [Fundamental epistemodidactic research of the pedagogical content and organization of the educational environment]. Novosibirsk, Publishing department of Institute of Pedagogical Research of Gifted Children of Russian Academy of education, 2016. 300 p. (In Russian).

3. Nikitina O.A. Primenenie faktorizaciy epistem v obrazovatel'nom processe application of epistemes' factorizations in educational process]. Izvestiya RGPU im. A.I. Gercena - Izvestia: Herzen University Journal of Humanities \& Sciences, 2013, no. 162, pp. 221-229 (In Russian).

4. Kozlov V.V., Nikitin A.A., Markovichev A.S., Miheev Yu.V., Nikitina O.A. Razvitie uchitel'skih kompetencyy, svyazannyh s gumanitarnymi aspektami ispol'zovaniya mnogourovnevyh testov development of teachers' competencies related to the humanitarian aspects of multi-level tests applications]. Pedagogika, 2019, no. 9, pp. 17-26 (In Russian). (The Journal indexed in RSCI (Web of Science)).

5. Kozlov V.V., Nikitin A.A., Belonosov V.S., Maltsev A.A., Markovichev A.S., Miheev Yu.V., Fokin V.M. Matematika: uchebnik dlya 5 klassa obshcheobrazovatel'nyh organizaciy [Mathematics: textbook for the $5^{\text {th }}$ grade of general education organizations]. Edited by V.V. Kozlov and A.A. Nikitin. Moscow, Russkoe slovo - uchebnik Publ., 2014. 352 p. (In Russian).

6. Kozlov V.V., Nikitin A.A., Belonosov V.S., Maltsev A.A., Markovichev A.S., Miheev Yu.V., Fokin V.M. Matematika: uchebnik dlya 6 klassa obshcheobrazovatel'nyh organizaciy [Mathematics: textbook for the $6^{\text {th }}$ grade of general education organizations]. Edited by V.V. Kozlov and A.A. Nikitin. Moscow, Russkoe slovo - uchebnik Publ., 2015. 328 p. (In Russian).

7. Kozlov V.V., Nikitin A.A., Belonosov V.S., Maltsev A.A., Markovichev A.S., Miheev Yu.V., Fokin V.M. Matematika: uchebnik dlya 7 klassa obshcheobrazovatel'nyh organizaciy [Mathematics: textbook for the $7^{\text {th }}$ grade of general education organizations]. Edited by V.V. Kozlov and A.A. Nikitin. Moscow, Russkoe slovo - uchebnik Publ., 2015. 384 p. (In Russian).

8. Kozlov V.V., Nikitin A.A., Belonosov V.S., Maltsev A.A., Markovichev A.S., Miheev Yu.V., Fokin V.M. Matematika: uchebnik dlya 8 klassa obshcheobrazovatel'nyh organizaciy [Mathematics: textbook for the $8^{\text {th }}$ grade of general education organizations]. Edited by V.V. Kozlov and A.A. Nikitin. Moscow, Russkoe slovo - uchebnik Publ., 2016. 368 p. (In Russian).

9. Kozlov V.V., Nikitin A.A., Belonosov V.S., Maltsev A.A., Markovichev A.S., Miheev Yu.V., Fokin V.M. Matematika: uchebnik dlya 9 klassa obshcheobrazovatel'nyh organizaciy [Mathematics: textbook for the $9^{\text {th }}$ grade of general education organizations]. Edited by V.V. Kozlov and A.A. Nikitin. Moscow, Russkoe slovo - uchebnik Publ., 2015. 376 p. (In Russian).

10. Kozlov V.V., Nikitin A.A., Belonosov V.S., Maltsev A.A., Markovichev A.S., Miheev Yu.V., Fokin V.M. Matematika: algebra $i$ nachala matematicheskogo analiza, geometriya: uchebnik dlya 10 klassa obshcheobrazovatel'nyh organizaciy. Bazovyi i uglublennyi urovni [Mathematics: algebra and pre-calculus: textbook for the $10^{\text {th }}$ grade of general education organizations. Basic and advanced level]. Edited by V.V. Kozlov and A.A. Nikitin. Moscow, Russkoe slovo - uchebnik Publ., 2014. 464 p. (In Russian).

11. Kozlov V.V., Nikitin A.A., Belonosov V.S., Maltsev A.A., Markovichev A.S., Miheev Yu.V., Fokin V.M. Matematika: algebra $i$ nachala matematicheskogo analiza, geometriya: uchebnik dlya 11 klassa obshcheobrazovatel'nyh organizaciy. Bazovyi $i$ uglublennyi urovni [Mathematics: algebra and pre-calculus: textbook for the $11^{\text {th }}$ grade of general education organizations. Basic and advanced level]. Edited by V.V. Kozlov and A.A. Nikitin. Moscow, Russkoe slovo - uchebnik Publ., 2015. 400 p. (In Russian).

12. Kozlov V.V., Nikitin A.A., Belonosov V.S., Maltsev A.A., Markovichev A.S., Miheev Yu.V., Fokin V.M. Matematicheskiy praktikum po kursu "Matematika": 2 kontrol'no-izmeritel'nyh materiala dlya 10-11 klassov 
obshcheobrazovatel'nyh organizaciy [Mathematics workshop: 2 assessment tutorials for the $10^{\text {th }}-11^{\text {th }}$ grades of general education organizations]. Edited by V.V. Kozlov and A.A. Nikitin. Moscow, Russkoe slovo - uchebnik Publ., 2017 (In Russian).

13. Kozlov V.V., Nikitin A.A., Belonosov V.S., Maltsev A.A., Markovichev A.S., Miheev Yu.V., Fokin V.M. Kniga dlya uchitelya $k$ uchebniku "Matematika", 5 klass [Teachers' book to the textbook "Mathematics", $5^{\text {th }}$ grade]. Edited by V.V. Kozlov and A.A. Nikitin. Moscow, Russkoe slovo - uchebnik Publ., 2013. 256 p. (In Russian).

14. Kozlov V.V., Nikitin A.A., Belonosov V.S., Mal'cev A.A., Markovichev A.S., Miheev Yu.V., Fokin V.M Kniga dlya uchitelya $k$ uchebniku "Matematika", 6 klass [Teachers' book to the textbook "Mathematics", $6^{\text {th }}$ grade]. Edited by V.V. Kozlov and A.A. Nikitin. Moscow, Russkoe slovo - uchebnik Publ., 2013. 216 p. (In Russian).

15. Kozlov V.V., Nikitin A.A., Belonosov V.S., Mal'cev A.A., Markovichev A.S., Miheev Yu.V., Fokin V.M. Kniga dlya uchitelya $k$ uchebniku "Matematika", 7 klass [Teachers' book to the textbook "Mathematics", $7^{\text {th }}$ grade]. Edited by V.V. Kozlov and A.A. Nikitin. Moscow, Russkoe slovo - uchebnik Publ., 2013. 256 p. (In Russian).

16. Kozlov V.V., Nikitin A.A., Belonosov V.S., Mal'cev A.A., Markovichev A.S., Miheev Yu.V., Fokin V.M. Metodicheskoe posobie k uchebniku "Matematika: algebra and geometriya" dlya 8 klassa obshcheobrazovatel'nyh organizaciy [Teachers' book to the textbook "Mathematics: algebra and geometry" for the $8^{\text {th }}$ grade of general education organizations]. Edited by V.V. Kozlov and A.A. Nikitin. Moscow, Russkoe slovo - uchebnik Publ., 2015. 232 p. (In Russian).

17. Kozlov V.V., Nikitin A.A., Belonosov V.S., Mal'cev A.A., Markovichev A.S., Miheev Yu.V., Fokin V.M. Metodicheskoe posobie $k$ uchebniku "Matematika: algebra $i$ geometriya": posobie dlya 9 klassa obshcheobrazovatel'nyh organizaciy [Teachers' book to the textbook "Mathematics: algebra and geometry": teachers' book for the 9th grade of general education organizations]. Edited by V.V. Kozlov and A.A. Nikitin. Moscow, Russkoe slovo - uchebnik Publ., 2016. 440 p. (In Russian).

18. Kozlov V.V., Nikitin A.A., Belonosov V.S., Mal'cev A.A., Markovichev A.S., Miheev Yu.V., Fokin V.M. Metodicheskoe posobie k uchebniku "Matematika: algebra i nachala matematicheskogo analiza, geometriya": posobie dlya 10 klassa obshcheobrazovatel'nyh organizaciy [Teachers' book to the textbook "Mathematics: algebra and pre-calculus, geometry": teachers' book for the $10^{\text {th }}$ grade of general education organizations]. Edited by V.V. Kozlov and A.A. Nikitin. Moscow, Russkoe slovo - uchebnik Publ., 2015. 328 p. (In Russian).

19. Kozlov V.V., Nikitin A.A., Belonosov V.S., Mal'cev A.A., Markovichev A.S., Miheev Yu.V., Fokin V.M. Metodicheskoe posobie k uchebniku "Matematika: algebra i nachala matematicheskogo analiza, geometriya": posobie dlya 11 klassa obshcheobrazovatel'nyh organizaciy [Teachers' book to the textbook "Mathematics: algebra and pre-calculus, geometry": teachers' book for the $11^{\text {th }}$ grade of general education organizations]. Edited by V.V. Kozlov and A.A. Nikitin. Moscow, Russkoe slovo - uchebnik Publ., 2018. 320 p. (In Russian).

20. Kozlov V.V., Nikitin A.A., Belonosov V.S., Mal'cev A.A., Markovichev A.S., Miheev Yu.V., Fokin V.M. Programma kursa "Matematika”. 5-9 klassy ["Mathematics" course program. 5-9 grades] / Edited by V.V. Kozlov and A. A. Nikitin. Moscow, Russkoe slovo - uchebnik Publ., 2017. 136 p. (In Russian).

21. Kozlov V.V., Nikitin A.A., Belonosov V.S., Mal'cev A.A., Markovichev A.S., Miheev Yu.V., Fokin V.M. Rabochaya tetrad'k uchebniku "Matematika”: 20 tetradey dlya 5-9 klassov obshcheobrazovatel'nyh organizaciy [Workbook for the textbook "Mathematics": 20 workbooks for 5-9 grades of general education organizations]. Edited by V.V. Kozlov and A.A. Nikitin. Moscow, Russkoe slovo - uchebnik Publ., 20132018 (In Russian).

22. Kozlov V.V., Nikitin A.A., Belonosov V.S., Mal'cev A.A., Markovichev A.S., Miheev Yu.V., Fokin V.M. Tekushchiy i itogovyy kontrol' po kursu "Matematika": 5 posobiy dlya 5-9 klassov obshcheobrazovatel'nyh organizaciy [Current and final control tutorials for the course "Mathematics": 5 tutorials for 59 grades of general education organizations]. Edited by V.V. Kozlov and A.A. Nikitin. Moscow, Russkoe slovo - uchebnik Publ., 2014-2018 (In Russian).

23. Kozlov V.V., Nikitin A.A., Nikitina O.A. Matematika: uchebnik dlya 1 klassa obshcheobrazovatel'nyh organizaciy: $v 2$ chastyah [Mathematics: textbook for 1st grade of general education organizations]. Edited by V.V. Kozlov and A.A. Nikitin. Novosibirsk, Publishing and printing centre of Novosibirsk State University, 2021. Part 1. 172 p. (In Russian).

24. Kozlov V.V., Nikitin A.A., Nikitina O.A. Matematika: uchebnik dlya 1 klassa obshcheobrazovatel'nyh organizaciy: $v 2$ chastyah [Mathematics: textbook for 1st grade of general education organizations]. Edited by V.V. Kozlov and A.A. Nikitin. Novosibirsk, Publishing and printing centre of Novosibirsk State University, 2021. Part 2. 198 p. (In Russian). 
Alexander A. Nikitin, academic of Russian Academy of Education, doctor of physical and mathematical sciences, professor. Leading researcher, Sobolev Institute of Mathematics (Acad. Koptyug Avenue, 4, Novosibirsk, Russian Federation, 630090). Professor, Novosibirsk State University (Pirogova Street, 1, Novosibirsk, Russian Federation, 630090).

E-mail: aanikitin48@gmail.com

Olga A. Nikitina, doctor of pedagogical sciences. Leading researcher, Novosibirsk State University (Pirogova Street, 1, Novosibirsk, Russian Federation, 630090).

E-mail:niolga@mail.ru 